\title{
MEDIASI PENAL SEBAGAI ALTERNATIF PENYELESAIAN \\ PERKARA PENCURIAN RINGAN \\ (STUDI DI POLRES MALANG KOTA)
}

\author{
James Hasudungan Hutajulu \\ Polda Jatim \\ Jln. Ahmad Yani No. 116 Surabaya \\ Email: jameshutajulu@yahoo.com
}

\begin{abstract}
Research about implementation of penal mediation in resolving minor theft conducted by Malang Kota Resort Police is supposed to know and analyze the considerations of implementation of penal mediation and the steps of the implementation. The method used in this research was sociological law research or empirical research. The use of penal mediation as an alternative penal settlement of minor theft cases is in order to create a sense of fairness to parties so that people are satisfied with the services performed by the investigator. Another result, the implementation of penal mediation, namely: Reconciling the parties, the investigator witnessing the return of goods that were stolen by the offender, Help in making a letter of agreement with the parties, Receive a letter of revocation cases (police report), and doing a case discussion about it.
\end{abstract}

Key words: penal mediation, minor theft case, an alternative penal settlement

\begin{abstract}
Abstrak
Penelitian mengenai pelaksanaan mediasi penal pada tindak pidana pencurian ringan oleh Polres Malang Kota bertujuan untuk mengetahui dan menganalisis digunakannya mediasi penal serta menganalisis pelaksanaan mediasi penal sebagai alternatif penyelesaian perkara. Adapun metode yang digunakan adalah yuridis sosiologis atau jenis penelitian hukum sosiologis atau penelitian lapangan. Hasil penelitian yang diperoleh antara lain: Polres Malang Kota melakukan mediasi penal dengan alasan agar tercipta rasa keadilan terhadap para saksi sehingga masyarakat puas atas pelayanan yang dilakukan penyidik. Selain itu, langkah-langkah yang dilakukan dalam penerapan mediasi penal ini adalah mempertemukan para pihak, penyidik menyaksikan pengembalian barang yang dicuri oleh pelaku, membantu membuat surat kesepakatan bersama, menerima surat pencabutan perkara serta melakukan gelar perkara.
\end{abstract}

Kata kunci: mediasi penal, pencurian ringan, alternatif penyelesaian perkara 


\section{Latar Belakang}

Mendiskusikan tentang hukum, maka harus melibatkan masyarakat, karena hukum dan masyarakat tidak dapat dipisahkan. Von Savigny salah satu tokoh dan pakar di bidang sejarah hukum mengatakan bahwa hukum itu tidak dibuat melainkan berkembang dan tumbuh bersama masyarakat. ${ }^{1}$ Oleh karena itu hukum diciptakan untuk mengatur masyarakat agar tertib, aman, dan damai.

Pelaksanaan hukum dalam kehidupan masyarakat sehari-hari mempunyai arti yang sangat penting karena tujuan hukum adalah menciptakan keadilan, kepastian dan memberikan kemanfaatan bagi masyarakat. Ketiganya itu bukan jargon semata dan harus bisa diwujudkan dan diimplementasikan pada pelaksanaan hukum itu sendiri. Keadilan dalam masyarakat hanya dapat diwujudkan kalau hukum dilaksanakan. Hukum itu harus dilaksanakan dan dipatuhi oleh semua orang dan semua orang itu harus diperlakukan sama di depan hukum (equality before the law). Apabila hukum tidak ditegakkan, maka ia tidak akan mempunyai makna dalam kehidupan masyarakat. Peraturan hukum yang demikian akan mati dengan sendirinya. ${ }^{2}$

Mengenai mekanisme penegakan hukum dalam sistem peradilan pidana di Indonesia, tentunya akan mengacu pada Undang-undang Nomor 8 Tahun 1981 Tentang Kitab Undang- undang Hukum Acara Pidana (KUHAP), karena KUHAP ini berbicara mengenai tata cara atau prosedur sistem peradilan pidana Indonesia atau yang dikenal sebagai hukum acara untuk menegakkan hukum pidana materiil. Penegakan hukum pidana dimulai dari proses penyelidikan dan penyidikan di kepolisian, penuntutan oleh Jaksa penuntut umum di persidangan, dan vonis hukuman atau sanksi oleh Hakim. Jadi intinya penegakan hukum adalah salah satu bentuk penjatuhan hukuman (pidana). Berhubungan dengan hal tersebut, Sauer memberikan tiga pengertian dasar dalam hukum pidana, yaitu sifat melawan hukum, kesalahan dan pidana. ${ }^{3}$

Berbicara mengenai sistem hukum kita yang merupakan warisan dari Belanda, mengisyaratkan bahwa pelaksanaan pidana pada hakikatnya tidak terlepas dari kemauan masyarakat maupun kemauan negara untuk menciptakan rasa aman, tentram dan damai dalam menjalani kehidupan sehari-hari. Sejak dahulu sampai sekarang, permasalahan pidana telah menyerap banyak energi para anak bangsa untuk membangun rekonstruksi sosial. Peningkatan aktivitas kriminal dalam berbagai bentuk menuntut kerja keras dalam membangun pemikiran-pemikiran baru mengenai arah kebijakan di masa depan.

Arah kebijakan hukum bertujuan menjadikan hukum sebagai aturan yang

1 Lili Rasjidi dan Ira Thania Rasjidi, Pengantar Filsafat Hukum, Mandar Maju, Bandung, 2007, hlm. 63.

2 Imam Sukadi, Matinya Hukum dalam Proses Penegakan Hukum di Indonesia, Jurnal Risalah Hukum Volume 7 No.1, ISSN 021-969X, Fakultas Hukum Unmul, hlm. 35.

3 Dwidja Priyatno, Pemidanaan untuk Anak dalam Konsep Rancangan KUHP (dalam Kerangka Restorative Justice), Lembaga Advokasi Hak Anak (LAHA), Edisi VIII, Volume III, Bandung, 2007, hlm. 9. 
memberikan perlindungan bagi hak-hak warga negara dan menjamin kehidupan generasi di masa depan. Oleh karena itu, sistem hukum tiap negara dalam prakteknya terus mengalami modernisasi dan tidak ada satu negara yang dapat menolaknya. ${ }^{4}$

Pada umumnya ketentuan pidana masuk dalam ranah hukum publik artinya negara mempunyai peranan yang sangat vital untuk menegakkannya. Hal ini tentu berbeda dengan hukum perdata, yang titik tekannya pada persoalan individu. Pada pokoknya, hukum itu mengatur segala tingkah laku masyarakat untuk hidup bermasyarakat di dalam suatu negara. ${ }^{5}$

Lembaga Kepolisian sebagai ujung tombak dalam penegakan hukum pidana mempunyai tugas dan kewenangan apakah suatu perbuatan itu perlu dihentikan prosesnya atau perlu ditindaklanjuti dalam proses peradilan pidana dengan alasan-alasan tertentu. Payung hukum yang digunakan adalah Pasal 18 ayat (1) Undang-undang Nomor 2 Tahun 2002 tentang Kepolisian Negara Republik Indonesia, yang berbunyi "untuk kepentingan umum dan masyarakat, pejabat Kepolisian Negara Republik Indonesia dalam melaksanakan fungsi, tugas, dan wewenangnya dapat bertindak menurut penilaiannya sendiri”. Sedangkan di ayat (2)-nya, pelaksanaan ketentuan sebagaimana dimaksud dalam ayat (1) hanya dapat dilakukan dalam keadaan yang sangat perlu dengan memperhatikan peraturan perundang-undangan, serta Kode Etik Profesi Kepolisian Negara Republik Indonesia.

Kata diskresi atau discretion (Inggris) atau pouvir discretionnaire (Perancis) atau freis ermessen (Jerman) memiliki banyak definisi. Saut P. Panjaitan mendefinisikan diskresi sebagai suatu bentuk penyimpangan terhadap asas legalitas dalam pengertian wet matigheid van bestuur, jadi merupakan "kekecualian" dari asas legalitas. Sedangkan Benyamin mengartikan diskresi sebagai kebebasan pejabat pengambil keputusan menurut pertimbangannya sendiri. Dengan demikian, menurutnya setiap pejabat publik memiliki kewenangan diskresi. Sejalan dengan itu, Rycko Amelza Dahniel mengemukakan bahwa diskresi merupakan kewenangan polisi dalam melaksanakan pemolisian, yakni sebagai tindakan yang diambil untuk tidak melakukan tindakan hukum dengan tujuan untuk kepentingan umum, kemanusiaan, memberikan pencerahan atau pendidikan kepada masyarakat, dan tindakan diskresi bisa dilakukan oleh setiap anggota kepolisian yang bertugas atau menangani suatu kasus atau permasalahan dalam lingkup tugas dan kewenangannya. ${ }^{6}$

Beberapa contoh kasus yang terjadi di Indonesia yang salah satunya menimpa ibu Miniasih, 2 orang anaknya serta keponakannya yang mencuri $2 \mathrm{Kg}$ buah Randu (kapuk),

4 Marlina, Peradilan Pidana Anak di Indonesia: Pengembangan Konsep Diversi dan Restorative Justice, Refika Aditama, Bandung, 2009, hlm. 1-2.

5 Wirjono Projodikoro, Asas-asas Hukum Pidana di Indonesia, Refika Aditama, Jakarta, 2003, hlm. 2.

6 Rycko Amelza Dahniel, Diskresi Kepolisian dalam Nilai-nilai Dasar Hukum, KIK-UI, Jakarta, 2009, hlm. 8 . 
yang apabila dinominalkan, buah randu yang dipungut itu tidak lebih dari 10 ribu rupiah. Akibat dari perbuatannya itu, ibu Miniasih sempat mendekam di Rutan Rowobelang sebagai tahanan Polres Batang.

Kasus hampir sama juga menimpa Kolil (50) dan Basar Suyanto (41), warga Lingkungan Bujel, Kelurahan Sukorame, Kecamatan Mojoroto Kediri yang dituduh mencuri 1 butir buah semangka. Terdakwatidak memiliki niat menguasai atau menguntungkan diri sendiri dan tidak untuk diperjualbelikan. Mereka hanya mencoba ingin mengobati rasa haus dengan memakan buah semangka yang sudah complong (rusak). Contoh lainnya adalah kasus yang menimpa Nenek Minah (50), warga desa Darmakradenan Kabupaten Banyumas, yang oleh PT. Rumpun Sari Antan dituduh melakukan pencurian atas 3 biji buah kakao dan telah menjalani masa tahanan rumah selama tiga bulan.

Dan yang terakhir yaitu kasus pencurian sandal jepit dengan terdakwa berinisial AAL (15) seorang siswa SMKN 3 Palu Selatan, Sulawesi Tengah yang sampai ke persidangan juga. AAL harus menghadapi jerat Pasal 362 KUHP dengan ancaman maksimal tuntutan 5 tahun penjara.

Fenomena yang terjadi di atas merupakan beberapa kasus yang melukai rasa keadilan dalam masyarakat. Hukum yang berlaku di negeri ini hanya mengandalkan legalitas formal belaka. Bandingkan dengan koruptor kelas kakap yang ada di negeri ini, yang hanya di hukum begitu ringan, padahal mereka adalah penyebab negeri ini menderita penyakit kronis dan sudah sepantasnya diberi hukuman yang berat. Benar apa yang dikatakan oleh Lord Acton, bahwa hukum itu tumpul ke atas dan tajam ke bawah.

Melihat kasus-kasus yang sudah dikemukakan di atas, pertanyaannya adalah dapatkah kasus itu diselesaikan secara kekeluargaan tanpa dibawa ke persidangan? Apabila kita cermati kasus di atas, ini adalah pertentangan nilai kepastian hukum dengan nilai keadilan. Mereka memang sudah melakukan pencurian dan memenuhi unsur Pasal 362 KUHP, akan tetapi layakkah kasus itu dibawa persidangan?

Kota Malang sebagai kota pendidikan juga tidak terlepas dari adanya kasus pencurian. Salah satunya yang terjadi di MOG Jalan Kawi Malang, dimana seorang perempuan yang bernama Nuna Octaviani 18 tahun, bertempat tinggal di Jl. Jodipan Wetan Gang 1 Kota Malang, telah didapati melakukan pencurian satu potong pakaian di Center Point MOG Malang yang berharga sekitar 120 Ribu. Entah dengan alasan apa dia mencuri, pihak Kepolisian Malang Kota meminta kepada pelapor Kardi Wantoko (Pihak MOG) untuk melakukan mediasi karena barang yang dicuri itu jumlahnya hanya sedikit. ${ }^{7}$

Kasus serupa juga menimpa Diyan Prayogo 15 Tahun. Dia kedapatan melakukan pencurian di center point MOG Malang. Barang yang dicuri adalah sebuah pakaian 
yang kisaran harganya 80 Ribuan. Karena yang melakukan pencurian itu seorang anak di bawah umur, ${ }^{8}$ maka Pihak Polres Malang Kota meminta kepada pelapor untuk melakukan mediasi. ${ }^{9}$

Dalam bekerjanya sistem peradilan pidana Indonesia yang berlandaskan pada UndangUndang Nomor 8 Tahun 1981 tentang Hukum Acara Pidana (KUHAP), sistem peradilan pidana itu diawali di kepolisian, kejaksaan, dan hakim pada saat peradilan. Dalam proses sistem peradilan pidana, membutuhkan waktu yang agak lama dan panjang bahkan terkadang berbelit-belit, sehingga dibutuhkan sebuah terobosan hukum yakni dengan mengunakan mediasi penal. Mediasi penal merupakan salah satu bentuk dari pelaksanaan restorative justice. Mediasi penal merupakan sebuah langkah terobosan hukum dalam rangka pembaharuan hukum pidana. Mediasi penal erat hubungan dengan restorative justice.

Penggunaan mediasi penal sebagai alternatif peradilan pidana khususnya dalam tindak pidana pencurian ringan tidak terbilang baru dan bukan suatu keharusan untuk dilaksanakan, itupun tergantung pada sikap aparat penegak hukum. Namun seiring perkembangan zaman dan kebutuhan korban, mediasi penal yang merupakan sebuah terobosan hukum mempunyai manfaat yang banyak bagi kedua belah pihak yang berperkara dan memberikan keuntungan tersendiri kepada pelaku dan korban.
Untuk penanganan kasus pidana, sekilas mediasi penal hampir sama dengan yang kita kenal diskresi (discretion) yang dimiliki oleh lembaga sistem peradilan pidana kita, seperti kepolisian dan kejaksaan untuk menyaring kasus-kasus yang masuk untuk tidak meneruskan sebagian kasus tertentu melalui proses peradilan pidana. Namun demikian terdapat esensi yang berbeda dengan sistem diskresi tersebut. Mediasi penal lebih mengedepankan kepentingan pelaku tindak pidana dan sekaligus kepentingan korban, sehingga tercapai win-win solution yang menguntungkan pelaku tindak pidana dan korbannya. Dalam mediasi penal korban dipertemukan secara langsung dengan pelaku tindak pidana dan dapat mengemukakan tuntutannya sehingga dihasilkan perdamaian para pihak.

Mediasi Penal merupakan salah satu jalan alternatif untuk menyelesaikan perkara khususnya tindak pidana pencurian ringan. Melalui mediasi penal proses penanganan perkara dilakukan secara transparan sehingga dapat mengurangi penyimpangan yang seringkali terjadi dalam proses peradilan pidana tradisional. Mengingat banyaknya keuntungan yang ada pada mediasi penal, sebagaimana telah dipraktekkan di beberapa negara, maka diperlukan upaya berupa kajian untuk menerapkan mediasi penal dalam proses peradilan pidana Indonesia sebagai bagian dari sistem peradilan pidana di Indonesia.

8 Yakni masih 15 tahun, sedangkan seorang anak sudah dewasa jika sudah berumur 18 Tahun, lihat UU No. 23 tahun 2004 tentang Perlindungan Anak.

9 Data Polres Malang Kota Tahun 2012. 
Saat ini mediasi penal mulai sering dilakukan oleh Polri sejak terbitnya Surat Kapolri No Pol: B/3022/XII/2009/SDEOPS tanggal 14Desember 2009 tentang Penanganan Kasus Melalui Alternative Dispute Resolution (selanjutnya disebut ADR). Artinya surat Kapolri ini berlaku bagi kedua belah pihak (baik pelaku dan korban) apabila mereka sepakat untuk dilakukan mediasi dengan syarat tindak pidana yang dilakukan adalah tindak pidana ringan.

Mediasi penal sebagai alternatif sistem peradilan pidana dalam kasus pencurian ringan sangat dibutuhkan dan bahkan sangat diperlukan, dikarenakan: ${ }^{10}$
a. diharapkan dapat mengurangi penumpukan perkara;

b. merupakan salah satu proses penyelesaian sengketa yang dianggap lebih cepat, murah dan sederhana;

c. dapat memberikan akses seluas mungkin kepada para pihak yang bersengketa untuk memperleh keadilan, dan

d. memperkuat dan memaksimalkan fungsi lembaga pengadilan dan penyelesaian sengketa di samping proses menjatuhkan pemidanaan. ${ }^{11}$

Berdasarkan latar belakang masalah di atas, pokok permasalahan yang menjadi obyek pembahasan dalam tulisan ini adalah:

1. Mengapa mediasi penal digunakan sebagai alternatif penyelesaian perkara dalam tindak pidana pencurian ringan oleh Kepolisian Resort Malang Kota?
2. Bagaimana pelaksanaan mediasi penal sebagai alternatif penyelesaian perkara pada tindak pidana pencurian ringan di Kepolisian Resort Malang Kota?

Sedangkan tujuannya antara lain: pertama, untuk mengetahui dan menganalisis digunakannya mediasi penal sebagai alternatif penyelesaian perkara dalam tindak pidana pencurian ringan oleh Kepolisian Resort Malang Kota; Kedua, untuk mengetahui dan menganalisis penerapan dan pelaksanaan mediasi penal sebagai alternatif penyelesaian perkara tindak pidana pencurian ringan di Kepolisian Resort Malang Kota.

Untuk menjawab permasalahan di atas, penulis menggunakan metode penelitian empiris. Jenis penelitian yang digunakan adalah yuridis sosiologis atau dengan kata lain adalah jenis penelitian hukum sosiologis dan atau dapat disebut pula dengan penelitian lapangan, yaitu mengkaji ketentuan hukum yang berlaku serta apa yang terjadi dalam kenyataannya di masyarakat. ${ }^{12}$ Tulisan ini mengkaji tentang Pelaksanaan Mediasi Penal Sebagai Alternatif Penyelesaian Perkara Pada Tindak Pidana Pencurian Ringan (Studi di Kepolisian Resort Malang Kota). Lokasi penelitian dilakukan di kantor Kepolisian Resort Malang Kota dikarenakan di Kota Malang terdapat beberapa kasus pencurian ringan yang sudah diselesaikan dengan menggunakan mediasi penal dengan pendekatan restorative justice.

10 DS. Dewi dan Fatahillah A. Syukur, Mediasi Penal: Penerapan Restorative Justice di Pengadilan Anak Indonesia, Indie Publishing, Jakarta, 2011, hlm. 80.

11 DS. Dewi dan Fatahillah A. Syukur, Loc.cit., hlm. 80. 
Adapun teknik analisis data yang digunakan yaitu setelah semua data yang digunakan dalam penyusunan penelitian ini terkumpul (data lapangan maupun data kepustakaan), maka dilakukan analisis data. Analisis data yang diperoleh baik melalui wawancara, observasi lapangan maupun data dari studi kepustakaan akan diuraikan dan dijelaskan mengenai keadaan yang sebenarnya dan apa yang terjadi didalamnya.

Penulis menggunakan analisis data dengan metode yang bersifat deskriptif analitik. Penelitian deskriptif adalah penelitian yang bertujuan untuk menyusun gambaran atau potret suatu permasalahan tentang pola dan problematika. ${ }^{13}$ Penulis memaparkan data yang telah diperoleh dari penelitian lapangan melalui wawancara, observasi dan studi kepustakaan sehingga dapat dijadikan pedoman dalam pemecahan permasalahan.

\section{Pembahasan}

Pada pembahasan permasalahan berdasarkan hasil penelitian, dapat diuraikan sebagai berikut:

\section{A. Mediasi Penal sebagai Alternatif} Penyelesaian Perkara pada Tindak Pidana Pencurian Ringan oleh

\section{Kepolisian Resort Malang Kota}

Upaya penyelesaian sengketa alternatif (Alternative Dispute Resolution) tidak hanya dikenal dalam kaedah-kaedah hukum perdata, tetapi juga mulai dikenal dan berkembang dalam kaedah hukum pidana. Salah satu jenis ADR yang mulai dikembangkan dalam hukum pidana adalah dalam bentuk mediasi atau dikenal dengan istilah 'mediasi penal' (penal mediation). ${ }^{14}$

Mediasi penal untuk pertama kali dikenal dalam peristilahan hukum positif di Indonesia sejak keluarnya Surat Kapolri No Pol: B/3022/ XII/2009/SDEOPS tanggal 14 Desember 2009 tentang Penanganan Kasus Melalui Alternative Dispute Resolution (ADR) meskipun sifatnya parsial. Pada intinya prinsip-prinsip mediasi penal yang dimaksud dalam Surat Kapolri ini menekankan bahwa penyelesaian kasus pidana dengan menggunakan ADR, harus disepakati oleh pihak-pihak yang berperkara namun apabila tidak terdapat kesepakatan baru diselesaikan sesuai dengan prosedur hukum yang berlaku secara profesional dan proporsional.

Polres Malang Kota dalam beberapa kasus pencurian khususnya pencurian ringan sudah menerapkan mediasi penal. Berikut Rekapitulasi perkara yang ditangani oleh Penyidik Satreskrim Polres Malang Kota yang telah diselesaikan dengan mediasi penal dalam kurun waktu tahun 2012 s.d. 2014, sebagai berikut:

Menurut Aji Lukmansyah, penerapan mediasi penal sebagai alternatif penyelesaian perkara pencurian sangat efektif dan efesien.

12 Bambang Waluyo, Penelitian Hukum dalam Praktek, Sinar Grafika, Jakarta, 2002, hlm. 15.

13 Endang Poerwanti, Dimensi-dimensi Riset Ilmiah, UMM Pers, Malang, 1998, hlm. 26.

14 CSA Teddy Lesmana, Mediasi Penal, Sebuah Transplantasi Hukum dalam Sistem Peradilan Pidana, www.jambilawclub.com, diakses 2 Nopember 2014 pukul 10.00 WIB. 
Tabel 2.1. Rekapitulasi Jumlah Perkara yang di Mediasi Penal oleh Satreskrim Polres Malang Kota

\begin{tabular}{|c|c|r|r|c|}
\hline No & Tahun & Jumlah Perkara & $\begin{array}{c}\text { Jumlah Perkara Pen- } \\
\text { curian Ringan }\end{array}$ & Keterangan \\
\hline 1. & 2012 & 42 & 10 & Mediasi Penal \\
\hline 2. & 2013 & 8 & - & Mediasi Penal \\
\hline 3. & 2014 & 25 & 1 & Mediasi Penal \\
\hline
\end{tabular}

Sumber: Urmintu Satreskrim Polres Malang Kota

Hal ini juga akan menciptakan adanya rasanya keadilan terhadap saksi, korban, dan tersangka sehingga masyarakat puas atas pelayanan penyidik. ${ }^{15}$ Hal senada juga dikatakan oleh Mudjianto, bahwa tidak semua kasus itu harus diselesaikan sampai ke tingkat pengadilan. Perkara yang diselesaikan dengan mediasi penal menimbulkan adanya rasa keadilan dalam masyarakat. ${ }^{16}$

Menurut Rudy Hidajanto, mediasi penal sering dilakukan oleh Polres Malang Kota terkait perkara yang tidak ada indikasi untuk komplain. Adapun persyaratan yang harus dipenuhi oleh pihak saksi, korban, dan tersangka adalah pertama, harus ada surat kesepakatan bersama antara saksi, korban, dan tersangka serta kedua, harus ada surat pencabutan laporan polisi dari pihak korban. Dengan adanya dua syarat tersebut, tentu dengan digunakannya mediasi penal akan menimbulkan rasa keadilan bagi saksi, korban dan tersangka. ${ }^{17}$
Menurut Evi Andriani, dilakukannya mediasi penal sebagai salah satu alternatif menyelesaikan perkara pencurian ringan adalah untuk menghindari dampak sosial masyarakat yang kadang-kadang membuat penyidik dipojokkan. ${ }^{18}$ Berbeda dengan pendapat di atas, Rudy Hidajanto menjelaskan bahwa digunakannya mediasi penal dalam kasus pencurian ringan adalah untuk meningkatkan kepercayaan masyarakat kepada pihak Polres Malang Kota. Namun apabila ternyata si pelaku pencurian tersebut sering melakukan kejahatan, maka penyidik tidak akan memediasi penyelesaian dengan pertimbangan agar pelaku memiliki rasa jera. ${ }^{19}$

Menurut KUHP, pencurian ringan (gepriviligeerde diefsal) diatur dalam Pasal 364 KUHP yang rumusannya sebagai berikut:

"perbuatan-perbuatan yang diterangkan dalam pasal 362 dan 363 butir 4, begitupun perbuatanperbuatan yang diterangkan dalam

15 Wawancara dengan Aipda Aji Lukmansyah, S.H., Anggota Satreskrim Polres Malang Kota, 10 Nopember 2014.

16 Wawancara dengan Brigadir Mudjianto, S.H., Anggota Satreskrim Polres Malang Kota, 10 Nopember 2014.

17 Wawancara dengan Ipda Rudy Hidajanto, S.H., Anggota Satreskrim Polres Malang Kota, 11 Nopember 2014.

18 Wawancara dengan Bripka Evi Andriani, S.H., Anggota Satreskrim Polres Malang Kota, 11 Nopember 2014.

19 Wawancara dengan Ipda Rudy Hidajanto, S.H., Anggota Satreskrim Polres Malang Kota, 11 Nopember 2014. 
pasal 363 butir 5, apabila tidak dilakukan dalam sebuah tempat kediaman, jika harga barang yang dicuri tidak lebih dari $\mathrm{Rp} 250,-$, diancam karena pencurian ringan dengan pidana penjara paling lama 3 bulan atau denda paling banyak $\mathrm{Rp}$ $900,-$.

Berdasarkan Pasal 364 KUHP di atas, jadi ada 3 kemungkinan saja yang dapat dikatakan sebagai pencurian ringan, yakni apabila: ${ }^{20}$

1. pencurian biasa sebagaimana diatur pasal 362, ditambah adanya unsur yang meringankan yakni apabila benda yag dicuri tidak lebih dari Rp 250,-

2. dua orang atau lebih melakukan pencurian dengan bersekongkol ditambah unsur nilai objeknya tidak melebihi dari $\mathrm{Rp}$ 250 ,-

3. pencurian itu dilakukan dengan cara masuk ke suatu tempat (tempat kejadian perkara) dengan cara: membongkar, merusak, memanjat, memakai anak kunci palsu, perintah palsu atau pakaian jabatan palsu, ditambah nilainya benda yang dicuri tidak lebih dari Rp 250,-.

Secara yuridis dalam sistem penegakan hukum pidana di Indonesia, sebenarnya para penegak hukum telah diberikan wewenang tertentu oleh undang-undang untuk mengesampingkan perkara pidana atau menyelesaian perkara pidana tanpa meneruskannya ke pengadilan (sarana non litigasi). Seperti halnya kepolisian, sebagaimana diatur dalam Pasal 18 Undangundang Nomor 2 Tahun 2002 tentang Polri, telah memberikan kewenangan kepada polisi (penyidik) untuk melakukan diskresi (discretion), yakni hak untuk tidak memproses hukum terhadap tindak pidana sepanjang demi kepentingan umum maupun moral, karena diskresi pada hakikatnya berada di antara hukum dan moral.

Dalam Pasal 18 ayat (1) Undangundang Nomor 2 Tahun 2002 tentang Polri menyebutkan bahwa "untuk kepentingan umum pejabat Kepolisian Negara Republik Indonesia dalam melaksanakan tugas dan wewenangnya dapat bertindak menurut penilaiannya sendiri”. Selanjutnya dalam ayat (2) disebutkan bahwa "pelaksanaan ketentuan sebagaimana dimaksud dalam ayat (1) hanya dapat dilakukan dalam keadaan yang sangat perlu dengan memperhatikan peraturan perundang-undangan, serta Kode Etik Profesi Polri”. Dalam penjelasan Pasal 18 Undangundang ini memberikan pengertian mengenai "bertindak menurut penilaian sendiri" sebagai suatu tindakan yang dapat dilakukan oleh anggota Polri yang dalam bertindak harus mempertimbangkan manfaat dan risiko serta biaya dan keuntungan (cost and benefit) dari tindakannya yang benar-benar untuk kepentingan umum.

Apabila dikaitkan dengan Pasal 18 Undang-undang Nomor 2 Tahun 2002 di atas, dalam Pasal 5 ayat (1) huruf a angka 4 dan Pasal 7 ayat (1) hurufj Undang-undang Nomor 
8 Tahun 1981 tentang Hukum Acara Pidana (KUHAP) menyatakan bahwa polisi selaku penyelidik maupun penyidik mempunyai wewenang untuk mengadakan tindakan lain menurut hukum yang bertanggung jawab. Yang dimaksud "tindakan lain" dalam penjelasan kedua pasal ini merupakan tindakan dari kepolisian (penyelidik/penyidik) untuk kepentingan penyelidikan/penyidikan dengan syarat: (a) tidak bertentangan dengan suatu aturan hukum, (b) selaras dengan kewajiban hukum yang mengharuskan dilakukannya tindakan jabatan, (c) tindakan itu harus patut dan masuk akal dan termasuk dalam lingkungan jabatannya, (d) atas pertimbangan yang layak berdasarkan keadaan yang memaksa, dan (e) menghormati hak asasi manusia.

Di samping itu, dalam rangka menjalankan tugas, Kepolisian Negara Republik Indonesia berwenang untuk mengadakan penghentian penyidikan. Penyidik karena kewajibannya mempunyai wewenang mengadakan penghentian penyidikan. Dalam Pasal 109 ayat (2) Undang-undang Nomor 8 Tahun 1981 (KUHAP) menyatakan bahwa polisi dalam hal ini penyidik dapat menghentikan penyidikan atas perkara tindak pidana karena: (1) tidak terdapat cukup bukti, (2) peristiwa tersebut ternyata bukan merupakan tindak pidana, atau (3) penyidikan dihentikan demi hukum. Dalam hal penyidik menghentikan penyidikan karena ketiga alasan dimaksud, maka penyidik memberitahukan hal ini kepada penuntut umum, tersangka atau keluarganya. Tentunya di sini juga perlu dipikirkan mengenai konsep tentang bagaimana dengan penghentian penyidikan atas dasar diskresi. Oleh karena itu, yang menjadi kesimpulan dari penulis adalah belum adanya kejelasan terkait batasan diskresi dalam kewenangan kepolisian (Pasal 18 Undang-undang Nomor 2 Tahun 2002), sehingga apabila polisi atau penyidik polri dengan menggunakan kewenangan diskresinya dalam menyelesaikan perkara pidana melalui mekanisme mediasi penal, maka yang terjadi adalah polisi atau penyidik tersebut telah melanggar hukum atau setidaktidaknya telah melangar hukum internalnya (baik peraturan disiplin maupun kode etik profesi polri). Hal ini dikarenakan kewenangan diskresi yang belum jelas batasannya tadi ditambah penggunaan mekanisme mediasi penal yang belum ada payung hukumnya. Mengingat Polri dalam setiap langkahnya selalu berdasarkan peraturan perundangundangan yang ada dan berlaku saat ini, maka Polri dalam melaksanakan tugas penegakan hukum selalu berdasarkan asas legalitas sebagai konsekuensi dari negara hukum yang dianut negara Indonesia.

Apabila mediasi penal (penal mediation) dikaitkan dengan ide keadilan restoratif (restorative justice) dan diskresi (discretion), maka dapat dikatakan bahwa ajaran atau nilai-nilai yang mendasari mediasi penal (penal mediation) adalah restorative justice, sedangkan roh mediasi penal (penal mediation) untuk mewujudkan keadilan restortaif (restorative justice) ada pada 
tiap-tiap institusi penegak hukum. Hal ini dapat diketahui seperti halnya jaksa punya deponeering dan polisi punya diskresi (discretion). Dengan demikian diskresi yang dimiliki institusi kepolisian merupakan roh atau sesuatu yang bisa menghidupkan atau setidak-tidaknya menjadi sumber inspirasi dimana mediasi penal dapat diterapkan pada tahap penyidikan oleh kepolisian sehingga akan menciptakan kedamaian bagi para pihak yang berperkara serta terwujudnya rasa keadilan yang dapat memulihkan para pihak dan masyarakat secara umum.

\section{B. Pelaksanaan Mediasi Penal sebagai Alternatif Penyelesaian Perkara pada Tindak Pidana Pencurian Ringan oleh Kepolisian Resort Malang Kota}

Dalam proses peradilan pada perkara pidana yang berupaya maksimal untuk menemukan dan mewujudkan kebenaran materiil, sering muncul keluhan ketidakadilan dari pihak yang berkepentingan (stakeholder) dalam perkara tersebut. Karena dalam perkara pidana stakeholder-nya tidak seperti dalam perkara perdata yaitu penggugat dan tergugat, tetapi lebih luas yaitu korban, pelaku dan masyarakat banyak terutama komunitas sekitar di mana kejahatan itu terjadi. Bahkan dalam perkara kejahatan luar biasa yang menyangkut kejahatan kemanusiaan, genosida, kejahatan perang dan agresi, stakeholder-nya adalah masyarakat internasional dan/atau bangsa- bangsa beradab. Dalam skala lokal, pelaku kejahatan kesusilaan di Indonesia bisa dikucilkan, ditolak atau dikeluarkan dari komunitasnya. Jika menyangkut kejahatan tertentu, suatu masyarakat dapat melakukan upacara atau kegiatan ritual sebagai upaya pemulihan keseimbangan agar jiwa komunal kemasyarakatan pulih kembali. Fenomena praktek hukum ini menunjukkan bahwa perbuatan pidana berada dalam kawasan publik dan tidak berada dalam ranah privat seperti hubungan keperdataan. ${ }^{21}$

Keterlibatan masyarakat sebagai komponen stakeholder dalam perkara pidana berbanding lurus dengan jangkauan tingkat berbahayanya kejahatan yang dilakukan. Komunitas masyarakat banyak sebagai stakeholder juga merupakan konsekuensi etis dari akibat yang ditimbulkan oleh kejahatan, sehingga menuntut rasa pertanggungjawaban kolektif dari masyarakat, karena berbahayanya kejahatan berada dalam ranah publik. Jika masyarakat beradab tidak melakukan reaksi terhadap perbudakan, pembunuhan massal atau kejahatan kemanusiaan lainnya, maka martabat kemanusiaan dapat berubah dan merosot menjadi setingkat dengan kebinatangan. Jika bangsa manusia tidak merespon terhadap penistaan martabat kemanusiaan, berarti tidak merasa bertanggung jawab dan mati rasa terhadap harkat kemanusiaan dirinya sendiri. Atensi, empati dan tanggung jawab stakeholder atas 
adanya kejahatan manusia terhadap manusia lainnya merupakan bagian dari sikap moral. Entitas tanggung jawab, niat, kesalahan dan rasa bersalah merupakan fokus acuan hukum pidana dan proses pengadilan perkara pidana.

Restorative justice bertujuan untuk mewujudkan pemulihan kondisi korban kejahatan, pelaku dan masyarakat berkepentingan (stakeholder) melalui proses penyelesaian perkara yang tidak hanya berfokus pada mengadili dan menghukum pelaku. Dalam proses pengadilan pidana konvensional, kepentingan korban seolaholah telah terwakili atau direpresentasikan oleh negara cq pemerintah cq kejaksaan dan kepolisian. Pertanyaannya, seberapa efektif dan representatif pemerintah dapat mewakili kepentingan korban kejahatan secara utuh? Perlu cermin besar untuk dapat melihat kepentingan korban kejahatan, karena menyangkut hak, martabat dan kemampuan insani dari korban selaku manusia yang berdaulat. Begitu pula hak dan kepentingan masa depannya. Apalagi kalau korban yang berstatus kepala keluarga yang mempunyai tanggungan anggota keluarga. ${ }^{22}$

Perkembangan ide mediasi penal tidak lepas dari perkembangan ide restorative justice sebagai salah satu ide pembaharuan hukum pidana (penal reform), karena konsep mediasi penal pada dasarnya merupakan salah satu sarana dalam mewujudkan pelaksanaan konsep restorative justice dalam penyelesaian perkara pidana. Mediasi penal sebagai mekanisme penyelesaian perkara pidana dalam mewujudkan keadilan restoratif (restorative justice).

Restorative justice merupakan suatu model pendekatan yang muncul dalam era tahun 1960-an dalam upaya penyelesaian perkara pidana. Berbeda dengan pendekatan yang dipakai pada sistem peradilan pidana konvensional, pendekatan ini menitikberatkan pada adanya partisipasi langsung pelaku. Terlepas dari kenyataan bahwa pendekatan ini masih diperdebatkan secara teoritis, akan tetapi pandangan ini pada kenyataannya berkembang dan banyak mempengaruhi kebijakan hukum dan praktik di berbagai negara. $^{23}$

Berangkat dari teori restoratifjustice inilah Polres Malang Kota menerapkan mediasi penal sebagai alternatif penyelesaian perkara dalam kasus pencurian ringan. Hal ini dikatakan oleh May Retnowati, bahwa mediasi penal dan restorative justice mempunyai hubungan yang erat dan memiliki tujuan yang sama yakni menyelesaikan perkara dengan melibatkan pihak tersangka dan korban sehingga rasa keadilan tercipta di masyarakat. ${ }^{24}$

Mengenai teknis pelaksanaan mediasi

22 Ibid., hlm. 27.

23 Eva Achjani Zulfa, Restorative Justice di Indonesia (Peluang dan Tantangan Penerapannya), Restorative Centre, http://evacentre.blogspot.com/p/restorative-justice-di-indonesia.html, diakses 20 Nopember 2014 pukul 11.00 WIB.

24 Wawancara dengan Aiptu May Retnowati, Anggota Satreskrim Polres Malang Kota, 10 Nopember 2014. 
penal yang dilakukan oleh Polres Malang Kota dalam menyelesaikan perkara pencurian ringan, dikemukakan oleh Aji Lukmansyah, yakni: ${ }^{25}$

1. mempertemukan para pihak (saksi, korban dan tersangka serta keluarga korban/tersangka);

2. menyaksikan pengembalian barang yang dicuri oleh pelaku atau ganti kerugian lain;

3. membantu membuat surat kesepakatan bersama para pihak (saksi, korban dan tersangka);

4. menerima surat pencabutan perkara (laporan polisi);

5. penyidik melakukan gelar perkara terhadap kasus tersebut untuk menentukan penyelesaiannya.

Senada dengan itu, Mudjianto menambahkan bahwa jika tersangkanya masih anak di bawah umur, maka orang tua wajib mendampinginya. Hal ini dilakukan untuk menjaga psikologis atau kejiwaan dari anak tersebut. Karena pada dasarnya seorang anak memiliki sisi psikologis yang lemah dan kadang dia tidak tahu apa yang diperbuatnya itu benar atau bertentangan dengan aturan yang berlaku. ${ }^{26}$

Menurut Santi Aman Wibowo, dari keseluruhan proses mediasi penal yang dilakukan oleh Polres Malang Kota, hal yang terpenting dan harus diperhatikan adalah adanya kesepakatan. Hal ini dikarenakan kesepakatanitu (para pihak) merupakan sebuah komitmen bersama untuk melakukan proses damai dengan cara-cara yang dibenarkan oleh hukum yang dituangkan dalam sebuah surat resmi yang ditandatangani oleh para pihak. ${ }^{27}$

Mediasi dalam perkara pidana dapat dilakukan dalam bentuk langsung atau tidak langsung, yaitu dengan mempertemukan para pihak (korban dan pelaku) secara bersamasama atau mediasi yang dilakukan oleh mediator secara terpisah (kedua belah pihak tidak dipertemukan secara langsung). Ini dapat dilakukan oleh mediator profesional atau relawan terlatih. Mediasi dapat dilakukan di bawah pengawasan lembaga peradilan pidana atau organisasi berbasis masyarakat yang independen dan selanjutnya hasil mediasi penal dilaporkan kepada otoritas peradilan pidana. ${ }^{28}$

Pelaksanaan mediasi penal oleh Polres Malang Kota dilakukan dalam bentuk langsung yaitu dengan mempertemukan para pihak (korban dan pelaku) secara bersamasama, dimana pihak penyidik Polres Malang Kota bertindak sebagai mediatornya. Hal ini dikatakan oleh Rudy Hidajanto bahwa tentunya pihak penydik sebagai mediator akan bersikap netral dan akan mengakomodir kepentingan para pihak. Lebih lanjut

25 Wawancara dengan Aipda Aji Lukmansyah, S.H., Anggota Satreskrim Polres Malang Kota, 10 Nopember 2014.

26 Wawancara dengan Brigadir Mudjianto, S.H., Anggota Satreskrim Polres Malang Kota, 10 Nopember 2014.

27 Wawancara dengan Briptu Santi Aman Wibowo, S.H., Anggota Satreskrim Polres Malang Kota, 10 Nopember 2014. 
ia menyatakan bahwa dengan adanya penyelesaian perkara di luar pengadilan (di tingkat kepolisian) maka perkara tersebut dianggap tuntas/selesai. Kemudian penyidik membuat SP2HP (Surat Pemberitahuan Perkembangan Hasil Penyidikan) kepada saksi pelapor bahwa perkara yang dilaporkan telah selesai secara kekeluargaan sehingga penyidik tindak menindaklanjuti lagi proses penyidikan. Dengan demikian sudah ada kepastian hukum dan masyarakat puas atas pelayanan petugas kepolisian. ${ }^{29}$

Kenyataan yang terjadi di lapangan, Polres Malang Kota juga mengalami kendala dalam melakukan penyelesaian perkara dengan mediasi penal. Hal ini diungkap oleh Mudjianto, yang mengatakan bahwa kendala yang sering dihadapi oleh Pihak Polres Malang Kota dalam menyelesaikan perkara dengan mediasi penal adalah tersangka tidak mengakui perbuatannya, barang bukti tidak ada pada pelaku, dan korban tidak mau diselesaikan secara kekeluargaan dan tetap meminta perkara diselesaikan sampai ke tingkat pengadilan. ${ }^{30}$ Apabila ketiga unsur ini belum terpenuhi, mustahil mediasi penal dapat dilakukan.

Apabila kita cermati secara seksama, sebenarnya ide penyelesaian perkara pencurian ringan dengan mediasi penal terletak pada korban dan didukung oleh tersangka yang kooperatif mengakui segala perbuatannya. Namun, apabila si korban tidak mau menyelesaikannya secara kekeluargaan melalui mediasi penal, maka perkara akan harus dilanjutkan ke tingkat selanjutnya.

Sebagai langkah terakhir, apabila korban masih bersikukuhuntuk melanjutkan ke tingkat persidangan, maka pihak Polres Malang Kota mencoba menasehati dan menjelaskan duduk persoalannya yang salah salah satunya adalah memberikan pengertian bahwa nilai barang yang dicuri itu adalah ringan. ${ }^{31}$ Akan tetapi semuanya akan tetap kembali pada kemauan dan kehendak pada diri si korban karena korban adalah pihak yang dirugikan.

Kendala lainnya, adalah apabila setelah terjadikesepakatan bersama para pihak(korban dan tersangka) dan telah ada pencabutan Laporan Polisi oleh korban tetapi kemudian setelah itu, korban datang dan meminta kembali agar kasusnya dilanjutkan, penyidik akan menjelaskan bahwa kesepakatan itu telah menjadi perjanjian kedua pihak dan bersifat mengikat serta kasus itu pun telah dihentikan penyidikannya. ${ }^{32}$

Saran/rekomendasi yang dapat penulisan berikan dalam tulisan ini antara lain: pertama, perlu dibangun kesadaran bagi pengemban profesi di bidang hukum, baik kalangan

28 DS. Dewi dan Fatahillah A. Syukur, Op.cit., hlm. 93.

29 Wawancara dengan Ipda Rudy Hidajanto, S.H., Anggota Satreskrim Polres Malang Kota, 11 Nopember 2014.

30 Wawancara dengan Brigadir Mudjianto, S.H., Anggota Satreskrim Polres Malang Kota, 11 Nopember 2014.

31 Wawancara dengan Briptu Santi Aman Wibowo, S.H., Anggota Satreskrim Polres Malang Kota, 10 Nopember 2014.

32 Wawancara dengan Ipda Ipda Rudy Hidajanto, S.H., Anggota Satreskrim Polres Malang Kota, 11 Nopember 2014. 
akademisi maupun praktisi tentang perlunya penerapan mekanisme mediasi penal (penal mediation) dalam sistem peradilan pidana Indonesia di masa mendatang sebagai alternatif dalam penyelesaian perkara tindak pidana pencurian ringan termasuk perlunya lembaga mediasi penal sebagai pendukung pelaksanaan mediasi penal, agar pencapaian tujuan hukum dapat diwujudkan baik keadilan, kemanfaatan, maupun kepastian hukum di dalam masyarakat. Dan kedua, konsep keadilan restoratif perlu diformulasikan dalam payung hukum yang kuat yakni undang-undang sebagai landasan legalitas mengimplementasikan dalam penanganan perkara pidana. Kebijakan formulatif ini dapat didahului oleh Polri dengan diterbitkannya suatu peraturan kepolisian terutama berupa Peraturan Kapolri sebagai acuan atau pedoman bagi penyidik.

\section{Simpulan}

Digunakannya mediasi penal sebagai alternatif penyelesaian perkara pencurian ringan yang dilakukan oleh Polres Malang Kota dilatarbelakangi oleh beberapa hal, yaitu: pertama, untuk menciptakan rasa keadilan terhadap para pihak yaitu: saksi, korban, dan tersangka, sehingga masyarakat puas atas pelayanan yang dilakukan oleh penyidik Polres Malang Kota. Karena tidak semua kasus harus diselesaikan sampai ke tingkat persidangan; Kedua, pelaksanaan mediasi penal juga dapat meningkatkan kepercayaan masyarakat terhadap Polri karena ada sebagian korban yang sebenarnya hanya ingin agar kerugiannya diganti daripada harus berperkara di pengadilan sehingga dengan mediasi penal masyarakat percaya bahwa Polri dapat menjadi mediator dalam penyelesaian perkara masyarakat; Dan ketiga, meningkatkan penyelesaian perkara dan mengurangi beban kerja penyidik.

Pelaksanaan mediasi penal yang dilakukan oleh Polres Malang Kota dalam menyelesaikan perkara pencurian ringan, dilakukan dengan langkah-langkah sebagai berikut: pertama, mempertemukan para pihak (saksi, korban dan tersangka maupun keluarga korban/ tersangka). Kedua, penyidik menyaksikan pengembalian barang yang dicuri oleh pelaku atau ganti kerugian lainnya. Ketiga, membantu membuat surat kesepakatan bersama para pihak (saksi, korban dan tersangka). Keempat, menerima surat pencabutan perkara (Laporan Polisi). Dan kelima, penyidik melakukan gelar perkara untuk penyelesaian kasus tersebut. 


\section{DAFTAR PUSTAKA}

Buku

Adami Chazawi, 1995, Kejahatan terhadap

Harta Benda, IKIP Malang, Malang.

Bambang Waluyo, 2002, Penelitian Hukum

dalam Praktek, Sinar Grafika, Jakarta.

DS. Dewi dan Fatahillah A. Syukur,

2011, Mediasi Penal: Penerapan

Restorative Justice di Pengadilan

Anak Indonesia, Indie Publishing, Jakarta.

Endang Poerwanti, 1998, Dimensi-dimensi

Riset Ilmiah, UMM Pers, Malang.

Lili Rasjidi dan Ira Thania Rasjidi, 2007,

Pengantar Filsafat Hukum, Mandar Maju, Bandung.

Marlina, 2009, Peradilan Pidana Anak di

Indonesia: Pengembangan Konsep

Diversi dan Restorative Justice, Refika Aditama, Bandung.

M. Sholehuddin, 2003, Sistem Sanksi dalam

Hukum Pidana, Ide Dasar Double

Track System dan Implementasinya,

RajaGrafindo Persada, Jakarta.

Rycko Amelza Dahniel, 2009, Diskresi

Kepolisian dalam Nilai-nilai Dasar

Hukum, KIK-UI, Jakarta.
Wirjono Projodikoro, 2003, Asas-asas Hukum Pidana di Indonesia, Refika Aditama, Jakarta.

Jurnal

Dwidja Priyatno, 2007, Pemidanaan untuk Anak dalam Konsep Rancangan KUHP (dalam Kerangka Restorative Justice), Lembaga Advokasi Hak Anak (LAHA), Edisi VIII, Volume III, Bandung.

Imam Sukadi, Matinya Hukum dalam Proses Penegakan Hukum di Indonesia, Jurnal Risalah Hukum Volume 7 No.1, ISSN 021-969X, Fakultas Hukum Unmul.

\section{Naskah Internet}

CSA Teddy Lesmana, Mediasi Penal, Sebuah Transplantasi Hukum dalam Sistem Peradilan Pidana, www. jambilawclub.com.

Eva Achjani Zulfa, Restorative Justice di Indonesia (Peluang dan Tantangan Penerapannya), Restorative Centre, http://evacentre.blogspot.com/p/ restorative-justice-di-indonesia.html. 